\title{
Estimation of Grassland Carrying Capacity by Applying High Spatiotemporal Remote Sensing Techniques in Zhenglan Banner, Inner Mongolia, China
}

\author{
Pengyao Qin ${ }^{1,2}$, Bin Sun ${ }^{1,2}$, Zengyuan Li $^{1,2}$, Zhihai Gao ${ }^{1,2, *}$, Yifu Li ${ }^{1,2}$, Ziyu Yan ${ }^{1,2}$ and Ting Gao ${ }^{1,2}$ \\ 1 Institute of Forest Resource Information Techniques, Chinese Academy of Forestry, Beijing 100091, China; \\ qpyhebei@126.com (P.Q.); sunbin@ifrit.ac.cn (B.S.); lizy@caf.ac.cn (Z.L.); li.yifu1314@163.com (Y.L.); \\ yanziyu96@163.com (Z.Y.); gaoting2167@126.com (T.G.) \\ 2 Key Laboratory of Forestry Remote Sensing and Information System, National Forestry and Grassland \\ Administration, Beijing 100091, China \\ * Correspondence: zhgao@ifrit.ac.cn
}

check for updates

Citation: Qin, P.; Sun, B.; Li, Z.; Gao, Z.; Li, Y.; Yan, Z.; Gao, T. Estimation of Grassland Carrying Capacity by Applying High Spatiotemporal Remote Sensing Techniques in Zhenglan Banner, Inner Mongolia, China. Sustainability 2021, 13, 3123. https://doi.org/10.3390/su13063123

Academic Editor: Antonio

Miguel Martínez-Graña

Received: 23 February 2021

Accepted: 9 March 2021

Published: 12 March 2021

Publisher's Note: MDPI stays neutral with regard to jurisdictional claims in published maps and institutional affiliations.

Copyright: (c) 2021 by the authors. Licensee MDPI, Basel, Switzerland. This article is an open access article distributed under the terms and conditions of the Creative Commons Attribution (CC BY) license (https:// creativecommons.org/licenses/by/ $4.0 /)$.

\begin{abstract}
Overgrazing directly leads to grassland degradation, which is a serious constraint to the sustainable development of animal husbandry. In drylands, grassland biomass is highly heterogeneous in space and time. It is difficult to achieve sustainable utilization of grassland resources by focusing only on the average annual carrying capacity assessment obtained from grass yield. Here, we proposed a novel approach for assessing grassland carrying capacity, taking Zhenglan Banner (County) in Inner Mongolia as the study area. First, monthly grass yield at $30 \mathrm{~m}$ spatial resolution was estimated, derived from Carnegie-Ames-Stanford Approach (CASA) model and spatial and temporal adaptive reflectance fusion model (STARFM). Then, based on the degree of sand mobility and degradation condition of typical steppe, the utilization patterns for sandy land and typical steppe in different grazing seasons were developed separately to obtain available grass yield. Finally, the carrying capacity at the Gacha (Village)-scale was estimated and the current livestock carrying status was evaluated to facilitate the grassland refined management. In Zhenglan Banner, the carrying capacity was 237.46 thousand cattle-units in summer. The grassland resources are being overgrazed, with an overload rate of $19.32 \%$. At Gacha-scale, the maximum reasonable stock density was ranged from 0.06 cattle-unit/ha to 0.42 cattle-unit/ha. Fifty-one Gachas exhibited livestock overload. This study is expected to provide technical support and scientific reference data for ecological conservation and grassland management in the study area, as well as in dryland pastoral areas of northern China.
\end{abstract}

Keywords: drylands; grass yield; sand mobility; degradation condition; utilization pattern

\section{Introduction}

Global grasslands cover 3500 million hectares, accounting for about $26 \%$ of the world's land area and about 70\% of the agricultural land area [1]. Grasslands are one of the most important types of terrestrial ecosystems on Earth because of their ecological functions, such as wind protection, sand fixation, soil and water conservation, air purification, and biodiversity maintenance. Furthermore, grasslands have an important economic value as the basis for animal husbandry and the production of mutton, beef, dairy, and other products $[2,3]$. In China, natural grasslands are the largest terrestrial ecosystem, accounting for $41.7 \%$ of the country's total land area and play an important role in livestock production and ecological restoration [4-6]. Animal husbandry based on the natural grasslands has been operating in China for almost a thousand years. Grazing is the most common grassland use in China and has become the most dominant way of human interference that affects grassland community structure and function $[7,8]$. However, over the past century, little attention has been paid to the coordination of ecological protection and production functions in the grasslands [9]. Overgrazing not only causes ecological degradation 
but also greatly restricts the sustainable and healthy development of grassland animal husbandry [10-14].

Directly adopting grazing prohibition to restore the grassland ecosystem will not be conducive to the sustainable development of grassland animal husbandry. Meanwhile, several studies have shown that light to moderate grazing intensity practices can improve grassland productivity under certain environmental conditions [15-21]. Carrying capacity, a concept introduced to regulate grazing density and avoid overgrazing by livestock [22], can be summarized as the "ecologically sustainable stocking rates, considering vegetation production, site ecology and animal requirement" [23] (the "ecologically sustainable" component means ecological health was considered). In grassland management, it is expressed in terms of the number of livestock and days that they can graze on a certain area of grassland. The carrying capacity is calculated by developing a grassland resource utilization strategy (proper use factors) and estimating grass yield available for grazing and the daily feed requirements of livestock. Hence, estimating grassland carrying capacity is premised on ecological restoration and can be an effective tool to control and maintain the sustainability of grassland utilization, livestock production, and grassland ecosystem services [24].

For carrying capacity estimation, remote sensing can be an attractive application to estimate grass yield and track many immediate changes in grassland vegetation [25], as demonstrated by several attempts to study such capacity [26-30]. Remote sensing technology can solve the shortcomings of traditional methods, which are time-consuming, labor-intensive, and limited by management-related spatial scale [29]. In addition to providing large area coverage, remote sensing products also provide a higher temporal frequency of acquisition compared to traditional field sampling over large areas. Grass yield is one of the most significant indicators to determine carrying capacity [31-33]. Methods for achieving grass yield estimation using remote sensing can be broadly grouped into statistical, physical, and simulation models $[27,29,34,35]$. Currently, the statistical model is still a widely used method for estimating grass yield [36-39]. The model was pioneered by Tucker et al. [40] and Tucker et al. [41], who predicted grass yield by investigating the empirical relationship between remote sensing variables and ground truth data for inversion (See also Liu et al. [42]; Jin et al. [43]). Although the model is simple and the calculation is easy to operate, this method is not widely used for carrying capacity assessment. The reason for this phenomenon is that this model is built according to a specific location or seasonality, its transferability to other areas is unknown, and it is susceptible to the influence by vegetation types and non-vegetation factors (soil background, atmospheric conditions, topography, and bidirectional reflectance signature of land surface) [44]. The temporal and spatial transferability of grass yield estimation approaches is of great important for reproducible applications and coverage of large areas [45]. The second approach is a physical model, which refers to the estimation of grass yield from remote sensing information with the help of the relationship between the bidirectional reflection and grass yield. Presently, the models applied to estimate grass yield are mainly radiative transfer models [34]. Quan et al. [46] used leaf area index and dry matter content to estimate a plateau grass yield in China based on the radiative transfer model PROSAILH. Punalekar et al. [47] combined proximal hyperspectral and Sentinel 2A with a radiative transfer model (PROSAIL) to estimate pasture yield in a dairy farming context. Compared to statistical models, the radiative transfer model-based approach provides higher robustness and reproducibility for estimating grass yield on a large scale without the need to collect field measurements $[46,47]$. However, there is a well-known ill-posed problem when inverting the radiative transfer models [48-50]. Moreover, the models are complex and computationally intensive, and difficulties are encountered in data acquisition and noise removal. The third approach is the simulation model (also known as the process model), which is to model grass yield based on the net primary production (NPP) estimated from remote sensing [51-54]. The model emphasizes the description of the various processes acting within the grassland ecosystem [55], and its estimation results are more reliable. In recent years, 
a large number of simulation models have been established, such as global production efficiency model (GLO-PEM) [56,57], bio-geochemical (BIOME-BGC) model [58], simple diagnostic biosphere model (SDBM) [59], TURC model [60], C-Fix model [61,62], vegetation photosynthesis model (VPM) [63,64], Lund university light use efficiency (LULUE) model [65], Eddy covariance-light use efficiency (ECLUE) model [66,67], organizing carbon and hydrology in dynamic ecosystems (ORCHIDEE) model [68], CENTURY model [69], and DeNitrification-DeComposition (DNDC) model [70], etc. Among the many models, a large majority of the studies investigated grass yield based on satellite data using a light use efficiency (LUE) model [32,34,71], suggesting that the LUE models are very effective and the most promising research tools [72]. The Carnegie-Ames-Stanford Approach (CASA) LUE model was mostly used among the published studies [54,73-75].

However, not all the estimated grass yield can be used for livestock rearing. If the grass utilization rate is too high, it will reduce the plant regeneration ability and the species diversity, and it will also affect the vegetation productivity and the sustainable use of grassland. On the contrary, if the grass utilization rate is too low, it is not conducive to the full utilization of grassland resources, and it is difficult to obtain the benefits of livestock production [20]. Thus, the development of a grassland utilization strategy to determine available grass yield is important for the coordination of grassland ecological restoration and husbandry sustainable development [76]. Zhang et al. [77] determined grassland utilization strategies for both cold and warm seasons based on grassland vegetation types and grazing utilization patterns with reference to the industry standard NY/T 635-2002 and estimated livestock carrying capacity for the Three-River Headwaters Region. Kuang et al. [30] developed a year-round grassland utilization strategy for 24 farms and ranches of the Hulunbuir Agricultural Reclamation Group based on grassland utilization patterns and assessed the ecological carrying capacity and the overloading condition of grassland. Neudert et al. [78] developed a grassland use strategy for obtaining maximum available grass yield in the continuously grazed area of the Greater Caucasus and calculated the potential grazing rate in the region. Hunt et al. [32] took Wyoming as a study area to determine grassland use strategies based on vegetation community type and calculated stocking rates per acre of animal unit month. To better cope with the complex characteristics of grassland ecosystem dynamics and uncertainty, Yu et al. [79] used slope, distance from water sources, and soil erosion intensity as limiting factors to formulate grassland use strategies and adjust the theoretical livestock carrying capacity. De Leeuw et al. [80] introduced a slope factor to further limit the amount of available grass yield on a slope greater than $10 \%$ when developing a grassland use strategy, thereby preventing the occurrence of soil erosion on a steep slope. The existing grassland use strategy focuses on the maximum available grassland yield and less on determining the sustainable available grassland yield from the current state of the grassland ecosystem.

Zhenglan Banner, Inner Mongolia, China, is located in the typical semi-arid grassland zone and the core area of Beijing-Tianjin Sand Source Region, which is an important ecological barrier for North China. Grassland-based livestock production is the foundation of the economy over there. Currently, the irrational use of grassland resources has made the grassland ecosystem more vulnerable, resulting in a poor ecological environment and seriously affecting local socioeconomic development [81]. How to achieve a balance between grassland ecological restoration and livestock development is an urgent issue.

In this context, this study aimed at proposing a novel approach to develop grassland utilization patterns and assess carrying capacity based on high spatiotemporal remote sensing techniques. This study taking Zhenglan Banner as an example for preliminary planning is expected to provide technical support and scientific reference for large-scale grassland conservation and utilization in both the study area and the entire dryland region of northern China. Specifically, the objectives of this study were to:

- develop spatiotemporal utilization patterns of grassland resource to obtain available grass yield, especially propose proper use factors with explicit spatial and temporal 
scales based on the current condition of grassland resources and seasonal changes in grass yield; and

- achieve an elaborate estimation of carrying capacity at Gacha (Village)-scale in the study area by taking the temporal and spatial advantage of the available grass yield estimation results.

This paper is structured as follows: Section 1 sets out existing methods for the two key parameters of grass yield and grassland utilization strategy in carrying capacity estimation; detailed introductions to the proposed carrying capacity estimation approach are presented in Section 2; the approach was implemented in Zhenglan Banner and carrying capacity estimation results are shown in Section 3; the improvement of the grass yield estimation model and performance of the grassland resource utilization patterns are discussed in Section 4; Section 5 concludes with a summary of the results and directions for future work.

\section{Materials and Methods}

\subsection{Study Area}

The Zhenglan Banner is located in the south of Xilin Gol League, Inner Mongolia, China, geographically between $41^{\circ} 56^{\prime}-43^{\circ} 11^{\prime} \mathrm{N}$ and $115^{\circ} 00^{\prime}-116^{\circ} 42^{\prime} \mathrm{E}$ and covering a total area of about 10,000 $\mathrm{km}^{2}$ (Figure 1) [81]. The terrain decreases from southwest to northeast with altitude ranging from 1200 to $1600 \mathrm{~m}$. The climate belongs to the arid continental monsoon climate in the middle temperate zone. The annual average temperature is $1.7^{\circ} \mathrm{C}$, and average annual precipitation and evaporation are $366.8 \mathrm{~mm}$ and $1936.2 \mathrm{~mm}$, respectively [82].

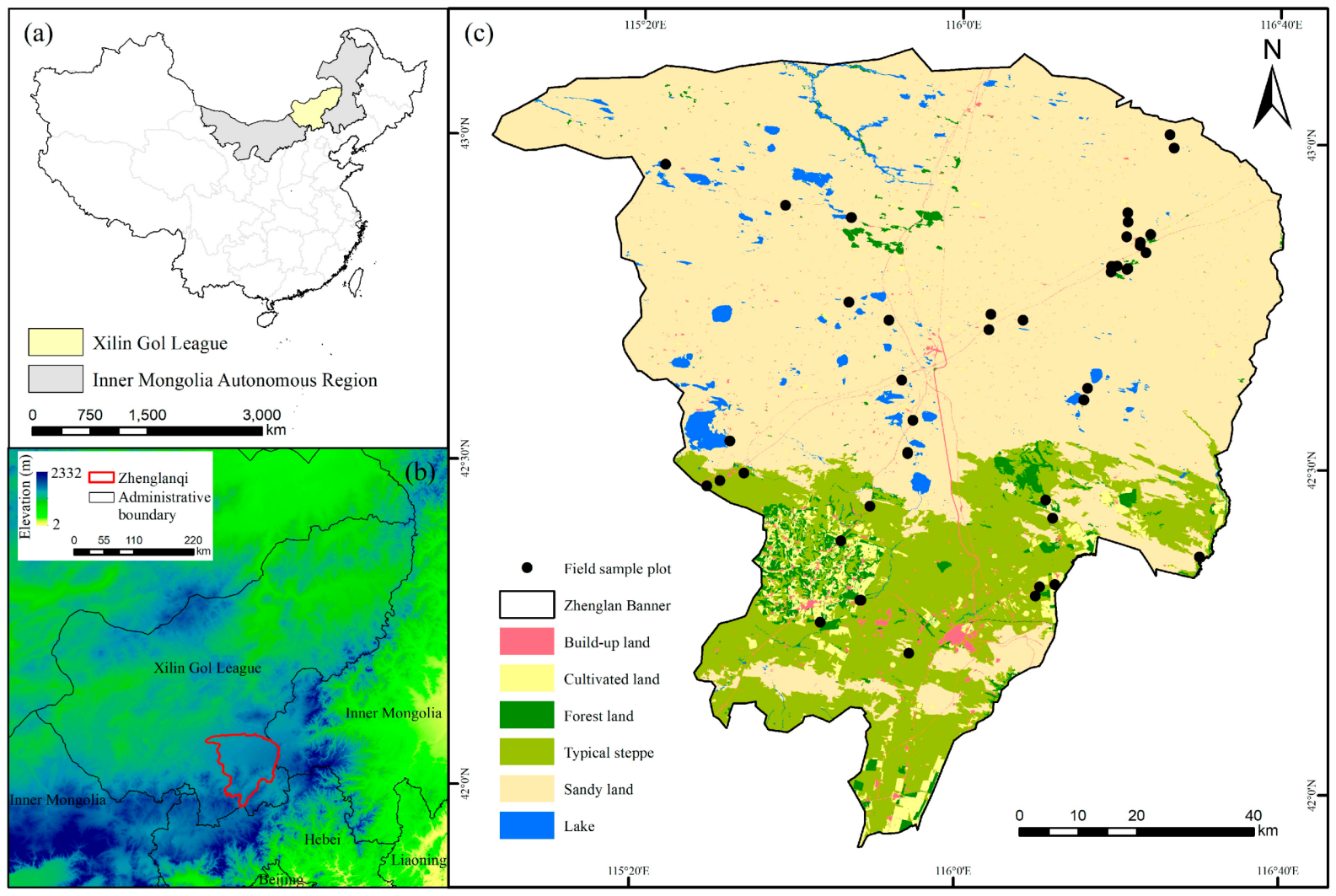

Figure 1. (a) Location of Xilin Gol League in China; (b) elevation distribution and location of the study area; and (c) land cover types in study area and the spatial distribution of grassland aboveground biomass field sample plots.

Natural grasslands are the advantageous resource in Zhenglan Banner, and the available grassland area accounts for $81.84 \%$ of the total land area. The natural grasslands in the northern part of the study area are distributed in the hinterland of the Otindag 
sandy land, which is one of the four semi-arid sandy areas in China and is covered by shifting sandy land, semi-fixed sandy land and fixed sandy land [83]. The southern part grows in the typical steppe of temperate zone. Due to the spatial heterogeneity of ecological factors such as moisture, substrate conditions, and terrain, natural grasslands have formed different vegetation types, which can be roughly divided into sand vegetation and steppe vegetation [82]. Sand vegetation is the largest and representative vegetation type in Zhenglan Banner [84], including Artemisia intramongolica H.C.Fu., Caragana microphylla Lam., Salix microstachya Turcz. ex Trautv var. bordensis (Nakai) C.F.Fang, Ulmus pumila Linn., Psammochloa villosa (Trin.) Bor, Polygonum divaricatum Linn., Corispermum mongolicum Iljin, Agriophyllum squarrosum (Linn.) Moq., etc. Steppe vegetation is zonal vegetation in the area [84], such as Leymus chinensis (Trin.) Tzvel., Stipa krylovii Roshev., Artemisia frigida Willd., Cleistogenes squarrosa (Trin.) Keng, etc. This grassland vegetation usually turns green in early April and stops growing in early September [85].

Grassland animal husbandry is the leading industry and distinctive industry in Zhenglan Banner's economic development. In livestock production, herdsmen mainly adopt free-range grazing and supplementary feeding. The ecological status of Zhenglan Banner is extremely important because it is the closest typical grassland and desert land to Beijing and Tianjin. In recent years, a series of grassland conservation and construction national projects, such as the "Beijing-Tianjin sand source control", "returning grazing to grassland", "grassland ecological compensation and awarding", and "management of reclaimed grasslands in the agro-pastoralist zone", have been implemented in Zhenglan Banner [86-88]. The regional ecological environment has been greatly improved [89]. The local government has stepped up its efforts to restructure its animal husbandry, transformed how it grows, vigorously developed modern and efficient animal husbandry, and adopted a series of measures, such as "surround shift" and "raise more cattle and less sheep", to relieve pressure on grassland and improve economic efficiency [90]. However, the region is still affected by overgrazing with vegetation degradation. Therefore, ecological restoration and sustainable use of grasslands remain key issues [12,81].

\subsection{Data Collection and Processing}

\subsubsection{Remote Sensing Data}

In this study, 58 Landsat 8 Operational Land Imager (OLI) Collections Level-1 scenes (Path/Row: 124/30 and 124/31) during 2014-2016 and 9 Landsat 5 Thematic Mapper (TM) Collections Level-1 from June to August during 1985-1987 were collected from the U.S. Geological Survey (USGS) (http:/ / glovis.usgs.gov / (accessed on 11 March 2021)), which have a temporal resolution of 16 days and spatial resolution of $30 \mathrm{~m}$. The Landsat data were preprocessed with radiance calibration, atmospheric correction, mosaicking, and clipping and were projected into Universal Transverse Mercator (UTM) $50 \mathrm{~N}$ with a World Geodetic System (WGS-84) datum.

However, it is difficult to ensure that high-quality cloud-free Landsat data images were available every month for calculation of monthly Normalized Difference Vegetation Index (NDVI). The MOD13Q1 NDVI data (NASA, https:/ / ladsweb.modaps.eosdis.nasa.gov/ (accessed on 11 March 2021)) during 2014-2016 in the study area were obtained for the construction of high-resolution monthly NDVI datasets. The monthly MODIS NDVI data were merged by the maximum value composite (MVC) method. Furthermore, to eliminate abnormal changes caused by adverse effects, such as snow accumulation, cloud pollution, and data transmission errors, the Savitzky-Golay (S-G) filtering method [91] was used to reconstruct the monthly MODIS NDVI dataset. At the same time, all coarseresolution MODIS NDVI data were resampled into $30 \mathrm{~m}$ spatial resolution and reprojected as UTM $50 \mathrm{~N}$ with a WGS-84 datum, consistent with Landsat data for further use in image fusion model. 


\subsubsection{Meteorological Data and Land Use and Land Cover (LULC) Data}

The meteorological data and LULC data were used for monthly NPP estimation. Meteorological data (including monthly temperature, precipitation, and ground downward shortwave radiation) covering a period of 2014-2016 around the Zhenglan Banner, with a spatial resolution of $0.1^{\circ}$, were extracted from China meteorological forcing dataset (1979-2018) [92]. LULC data came from the land use change survey results of Zhenglan Banner in 2016, which were obtained by Technical Regulation for the Second National Land-use Investigation (TD/T 1014-2007) [93]. The LULC types were summarized into 5 categories including sandy land, typical steppe, farmland, build-up land, and water. All the above datasets, which were well quality controlled prior to delivery, were reprojected and resampled to the same spatial resolution as the monthly NDVI dataset. Besides, the meteorological data were resampled to the same temporal resolution as the monthly NDVI dataset.

\subsubsection{Field Investigations}

Considering that the official statistical data released may not be accurate, the livestock data based on Gacha as the statistical unit were derived from a walk-through survey to 109 Gachas in Zhenglan Banner in 2018, mainly including livestock number, species structure, age structure, and feeding methods. In the survey process, we divided into six groups and conducted questionnaires for each herding household in each Gacha to ensure the accuracy and comprehensiveness of the survey results.

The measured grass yield data were taken from 36 field sample plots obtained by the research group through the sample harvest method in July or August of each year from 2014 to 2016 in Zhenglan Banner grassland [81]. The data were used to validate the accuracy of grass yield estimation for the same location at the same time.

\subsubsection{Other Data}

The administrative boundary data of each Gacha in Zhenglan Banner were provided by the local government. The statistical auxiliary data such as livestock number and fenced grassland area were derived from the Zhenglan Banner Statistical Yearbook (2014-2016).

\subsection{Methodology}

\subsubsection{Estimation of Grass Yield at High Spatial and Temporal Resolution}

The estimation of monthly grass yield $\left(\mathrm{GY}, \mathrm{g} / \mathrm{m}^{2}\right)$ at $30 \mathrm{~m}$ spatial resolution during 2014 to 2016 was achieved based on the NPP prediction data with improved spatial resolution.

$$
\mathrm{GY}=\frac{\mathrm{cNPP}}{0.47} \times \mathrm{fAG},
$$

where $\mathrm{CNPP}$ is the cumulative value of NPP at a given period, which is expressed in $\mathrm{gC} / \mathrm{m}^{2}$, is converted to biomass using a biomass to carbon conversion factor of $0.47 \mathrm{C}$ [94]. The fAG represents the proportion of above-ground growth to total growth, and the value taken in this study is 0.26 [94]. There is a premise here that grass yield can be obtained by accumulating monthly NPP. This is a reasonable assumption for grassland ecosystems where aboveground biomass dies off during the winter months. The performance of the predicting GY was evaluated by comparing the measured grass yield data with the GY predicted by this study's estimation model for the same year and sites. The terms of the accuracy were represented by Mean Absolute Error (MAE) and Root-Mean-Square Error (RMSE).

The estimation process for the NPP prediction data with improved spatial resolution was as follows. First, the spatial and temporal adaptive reflectance fusion model (STARFM), which was proposed by Gao et al. [95], in synergy between Landsat 8 OLI NDIV data with high spatial but low temporal resolution and MODIS NDVI data with low spatial but high temporal resolution, was applied for reconstructing a continuous and evenly distributed NDVI dataset with high spatiotemporal resolution (30 m and 1 month) during 2014 to 2016. 
The core algorithm of STARFM was to determine pixel weights and conversion coefficients by identifying similar pixels between relatively high spatial resolution data and coarse spatial resolution data at the same time, following which determined relationship was used for the coarse spatial resolution data at another time to simulate the high spatial resolution data at that time. This model can greatly improve the accuracy of simulated NDVI data. Next, the monthly NPP was estimated using the CASA model. In this study, the two key parameters used in the CASA model, $\varepsilon$ and $\beta$, were optimized using both measured data and methods supported by our previous research [96,97] due to the sparse vegetation cover and relatively complex surface conditions in the study area. The parameters, therefore, fitted well to the characteristics of the vegetation and soil conditions. To some extent, the effects caused by the soil or sand matrix can be eliminated, resulting in relatively high accuracy estimates. Based on the simulated monthly NDVI data, synchronous meteorological data, and LULC data, the monthly NPP at $30 \mathrm{~m}$ spatial resolution was estimated during 2014 to 2016.

\subsubsection{Development of Spatiotemporal Utilization Pattern for Grassland Resource Determination of the Degree of Sand Mobility and Steppe Degradation}

Taking into account the characteristics of sandy land in Zhenglan Banner and the feasibility of implementing control measures, referring to the Technical Code of Practice on the Sandified Land Monitoring (GB/T 24255-2009) [98], fractional vegetation cover (FVC) was selected as a key indicator to grade the sand mobility. The mobility of sandy land was divided into five levels: shifting sandy land with FVC less than 10\%, semi-shifting sandy land with FVC between 10\% and 30\%, semi-fixed sandy land with FVC between $30 \%$ and $50 \%$, fixed sandy land with FVC between $50 \%$ and $70 \%$, and full-fixed sandy land with FVC greater than $70 \%$. Considering the influence of annual rainfall fluctuations on sand mobility, remote sensing images of three years from 2014 to 2016 were selected as data sources to reflect the general condition of surface cover in the 2010s.

Referring to the parameters for degradation, sandification, and salification of rangelands (GB19377-2003) [99] and combining with the degradation characteristics of typical steppe in Zhenglan Banner, the reduction rate of grass yield was selected as a key indicator for depicting the degradation state of typical steppe. By calculating the reduction rate of grass yield in the 2010s compared with that in the 1980s, the degree of steppe degradation was classified into four levels: severe degradation with a reduction rate greater than $50 \%$, medium degradation with a reduction rate between $20 \%$ and $50 \%$, light degradation with a reduction rate between $10 \%$ and $20 \%$, and no degradation with a reduction rate less than $10 \%$. To reflect the level of grass yield more accurately in different eras and reduce the influence of random factors such as annual precipitation on grass yield, the grass yield in the 2010s and 1980s was represented by averaging the 3-year grass yield from 2014-2016 and 1985-1987, respectively.

\section{Development of the Spatiotemporal Utilization Patterns of Grassland}

The grazing strategies for different grassland resource types were determined based on the degree of sand mobility and the characteristics of typical steppe (including the degree of degradation, current grass yield, and vegetation types). Then, based on the degree of sand mobility and typical steppe degradation, the proper use factors were obtained by referring to the calculation of rangeland carrying capacity (NY/T 635-2015) [100], experts interviews, and the livestock data survey results.

Based on the climate, vegetation growth rhythms, and grazing utilization characteristics of different seasons in the study area, the grazing seasons of grassland resource utilization were further divided to set different utilization intensity. In autumn and winter, the available grass yield mainly comes from the remaining grass yield of summer grassland resources after livestock gnawing and natural decline. To further improve the evaluation accuracy of the available grass yield in autumn and winter, the autumn and winter grass 
preservation rate (80\%) was introduced with reference to the Cui et al. [101] study on the dynamic of grass preservation rates in Xilingol grassland in the cold season.

\subsubsection{Evaluation of Available Grass Yield}

The available grass yield (AY, $\mathrm{kg} / \mathrm{ha}$ ) of the grassland resources was then evaluated using the equation:

$$
\mathrm{AY}=\mathrm{GY} \times \mathrm{PU},
$$

where GY is expressed in $\mathrm{kg} / \mathrm{ha}$, and PU is the proper use factors in spatiotemporal utilization patterns for grassland resources.

\subsubsection{Assessment of Carrying Capacity and Current Livestock Carrying Status}

The carrying capacity in number of Simmental cattle-unit/ha (CC) was calculated based on the available grass yield in different types of grassland resources during different grazing seasons:

$$
\mathrm{CC}=\frac{\mathrm{AY}}{\mathrm{FI} \times \mathrm{GD}^{\prime}}
$$

where FI is the daily food intake of a Simmental cattle-unit $\left(\mathrm{kg} \cdot \mathrm{day}^{-1} \cdot\right.$ one cattle-unit $\left.^{-1}\right)$ and GD is the number of grazing days (day). In China's pastoral areas, sheep unit is usually used as the standard livestock. All types of livestock were converted into standard sheep unit (conversion factors are detailed in NY/T 635-2015) [100], which is convenient for the government to count and control the number of livestock. An adult sheep weighing $45 \mathrm{~kg}$ and consuming $1.8 \mathrm{~kg}$ standard hay per day, or other livestock equivalent to this, is defined as one sheep unit (NY/T 635-2015) [100]. Based on the livestock data survey results in the study area and the local government's strategy of raising more cattle and less sheep [102], almost all the herders are mainly cattle breeders and the dominant breed of cattle is Simmental cattle. Zhenglan Banner has formed a grassland animal husbandry development model that focuses on feeding Simmental cattle [103]. It was more appropriate to choose the Simmental cattle-unit to calculate carrying capacity. Referring to NY/T 6352015 [100], 1 Simmental cattle-unit equals 8 sheep-units and consumes $14.4 \mathrm{~kg}$ standard hay per day.

Under fully grazed conditions (without supplemental feeding), the livestock carrying status is calculated as

$$
\mathrm{OR}=\frac{\mathrm{CC}-\mathrm{AS}}{\mathrm{CC}} \times 100 \% \text {, }
$$

where livestock overloading rate $(\mathrm{OR}, \%)$ shows whether grazing activities have exceeded the carrying capacity of an area over a certain period of time. A positive result indicates that the grassland is under-exploited, and a negative result indicates that it is over-exploited. AS is the actual stocking rate in number of Simmental cattle-unit/ha.

\section{Results and Analysis}

\subsection{Spatiotemporal Utilization Patterns for Grassland \\ 3.1.1. Seasons Available for Grazing}

The grazing time can be divided into three grazing seasons: (1) Summer (1 June to 30 September). This season is the peak season for the growth of vegetation, with the highest grass production, and livestock feeding method is mainly grazing. (2) Autumn and winter (1 October to 31 March). The grassland vegetation gradually dies off during this season, and the available grassland resource is dominated by the grasses remaining in summer. Livestock feeding method must be supplemented with forage other than grazing. (3) Spring (1 April to 31 May). This is the season of grassland vegetation emergence; overgrazing can seriously affect the growth of vegetation throughout the year. Livestock feeding method is to restrict grazing or even prohibit grazing. 


\subsubsection{Spatiotemporal Utilization Patterns in Sandy Land}

The grazing utilization strategies and proper use factors of different sandy lands are shown in Table 1. Full-fixed and fixed sandy land with high vegetation coverage is the dominant grazing utilization type, but livestock-rearing control and spring banning grazing are needed to prevent enhanced sand mobility. Semi-fixed sandy land also has relatively high vegetation cover; spring banning grazing and livestock-rearing control are recommended. Shifting and semi-shifting sandy land has low vegetation cover and large areas of bare sand that are unsuitable for grazing.

Table 1. Spatiotemporal utilization patterns in different sandy lands.

\begin{tabular}{|c|c|c|c|c|c|}
\hline \multirow{2}{*}{ Sand Mobility } & \multirow{2}{*}{ Grazing Strategies } & \multicolumn{4}{|c|}{ Proper Use Factors } \\
\hline & & Summer & Autumn and Winter & Spring & Annual \\
\hline Shifting & $\begin{array}{l}\text { Banning grazing all year } \\
\text { round }^{1}\end{array}$ & 0 & 0 & 0 & 0 \\
\hline Semi-shifting & $\begin{array}{l}\text { Banning grazing all year } \\
\text { round }^{1}\end{array}$ & 0 & 0 & 0 & 0 \\
\hline Semi-fixed & $\begin{aligned} & \text { Spring banning grazing }{ }^{2} \\
+ & \text { Livestock-rearing control }^{3}\end{aligned}$ & $30 \%$ & $80 \% \times 30 \%$ & 0 & $47 \%$ \\
\hline Fixed & $\begin{aligned} & \text { Spring banning grazing }{ }^{2} \\
+ & \text { Livestock-rearing control }^{3}\end{aligned}$ & $40 \%$ & $80 \% \times 40 \%$ & 0 & $59 \%$ \\
\hline Full-fixed & $\begin{aligned} & \text { Spring banning grazing }{ }^{2} \\
+ & \text { Livestock-rearing control }^{3}\end{aligned}$ & $50 \%$ & $80 \% \times 40 \%$ & 0 & $66 \%$ \\
\hline
\end{tabular}

${ }^{1}$ Banning grazing all year round means that the grassland resources cannot be used for grazing throughout the year to accelerate the recovery of grassland vegetation. ${ }^{2}$ Spring banning grazing means that grazing is not allowed in the grasslands during spring.

${ }^{3}$ Livestock-rearing control means lowering human intervention in grassland by limiting the number of livestock allowed to graze in a given area.

\subsubsection{Spatiotemporal Utilization Patterns in Typical Steppe}

The grazing utilization strategies and proper use factors in typical steppe are shown in Table 2. Non- and lightly degraded steppe have high vegetation coverage and vigorous vegetation growth. Grazing should be prohibited in spring, and livestock-rearing control is carried out in other seasons. When steppe suffers medium degradation, although vegetation cover is also relatively high, it is recommended to implement spring banning grazing and livestock-rearing control. Severely degraded steppe has low grass coverage and a large reduction in grass yield and banning grazing all year round must be carried out.

Table 2. Spatiotemporal utilization patterns in typical steppe.

\begin{tabular}{|c|c|c|c|c|c|}
\hline \multirow{2}{*}{$\begin{array}{l}\text { Degradation } \\
\text { Conditions }\end{array}$} & \multirow{2}{*}{ Grazing Strategies } & \multicolumn{4}{|c|}{ Proper Use Factors } \\
\hline & & Summer & Autumn and Winter & Spring & Annual \\
\hline Severe degradation & $\begin{array}{l}\text { Banning grazing all year } \\
\text { round }^{1}\end{array}$ & 0 & 0 & 0 & 0 \\
\hline $\begin{array}{l}\text { Medium } \\
\text { degradation }\end{array}$ & $\begin{aligned} & \text { Spring banning grazing }{ }^{2} \\
+ & \text { Livestock-rearing control }^{3}\end{aligned}$ & $20 \%$ & $80 \% \times 20 \%$ & 0 & $33 \%$ \\
\hline Light degradation & $\begin{aligned} & \text { Spring banning grazing }{ }^{2} \\
+ & \text { Livestock-rearing control }^{3}\end{aligned}$ & $40 \%$ & $80 \% \times 30 \%$ & 0 & $54 \%$ \\
\hline No degradation & $\begin{aligned} & \text { Spring banning grazing }{ }^{2} \\
+ & \text { Livestock-rearing control }^{3}\end{aligned}$ & $50 \%$ & $80 \% \times 40 \%$ & 0 & $66 \%$ \\
\hline
\end{tabular}

\footnotetext{
${ }^{1}$ Banning grazing all year round means that the grassland resources cannot be used for grazing throughout the year to accelerate the recovery of grassland vegetation. ${ }^{2}$ Spring banning grazing means that grazing is not allowed in the grasslands during spring.

${ }^{3}$ Livestock-rearing control means lowering human intervention in grassland by limiting the number of livestock allowed to graze in a given area.
} 


\subsection{Available Grass Yield of Grassland}

The grass yield was estimated for the 3 grazing seasons and the whole year using equation (1) based on the NPP prediction results. The accuracy of the model-estimated grass yield was validated using in situ measured data, and a RMSE of $47.47 \mathrm{~g} / \mathrm{m}^{2}$ and a MAE value of $37.27 \mathrm{~g} / \mathrm{m}^{2}$ were obtained, which showed that the estimated grass yield can be used to calculate available grass yield.

In Zhenglan Banner, total annual available grass yield was $625.76 \mathrm{kt}$, of which the available grass yield in summer was $416.78 \mathrm{kt}$, and the available grass yield in autumn and winter was $208.98 \mathrm{kt}$. The spatial distribution of available grass yield was similar in the grazing season and throughout the year (Figure 2). The areas with lower available grass yield were mainly clustered in the northwest and northeast, while the areas with higher available grass yield were distributed in the north and southeast. Through the regulation of spatiotemporal utilization pattern for grassland resources, the available grass yield offered by severely degraded steppe, shifting and semi-shifting sandy land was $0 \mathrm{~g} / \mathrm{m}^{2}$ throughout the year, and the available grass yield provided by all other grassland resource types was also $0 \mathrm{~g} / \mathrm{m}^{2}$ in spring. Full-fixed sandy land provided the highest available grass yield throughout the year and in autumn and winter, with values of $123.46 \mathrm{~g} / \mathrm{m}^{2}$ and $33.85 \mathrm{~g} / \mathrm{m}^{2}$, respectively; and in summer no degraded steppe supplied the highest available grass yield $\left(90.00 \mathrm{~g} / \mathrm{m}^{2}\right)$ (Table 3).
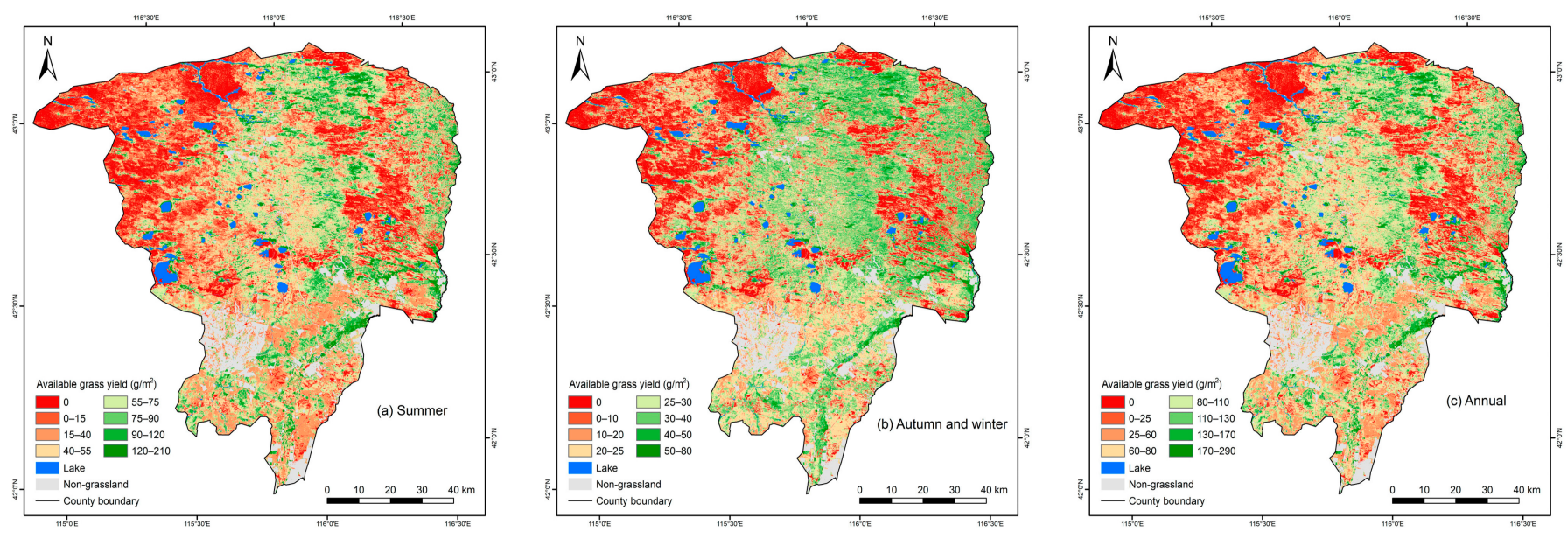

Figure 2. Spatial distribution of annual available grass yield and its distribution in different grazing seasons.

Table 3. Average available grass yield in different grassland types.

\begin{tabular}{ccccc}
\hline \multirow{2}{*}{ Grassland Resource Conditions } & \multicolumn{4}{c}{ Average Available Grass Yield $\left(\mathbf{g} / \mathbf{m}^{\mathbf{2}}\right)$} \\
\cline { 2 - 5 } & Spring & Summer & Autumn and Winter & Annual \\
\hline Full-fixed sandy land & 0 & 89.60 & 33.85 & 123.46 \\
Fixed sandy land & 0 & 61.19 & 33.83 & 95.03 \\
Semi-fixed sandy land & 0 & 38.96 & 0 & 03.82 \\
Semi-shifting sandy land & 0 & 0 & 0 & 0 \\
Shifting sandy land & 0 & 90.00 & 33.17 & 123.17 \\
No degraded steppe & 0 & 66.03 & 26.87 & 92.90 \\
Lightly degraded steppe & 0 & 32.71 & 22.80 & 55.52 \\
Medium degraded steppe & 0 & 0 & 0 & 0 \\
Severely degraded steppe & 0 & &
\end{tabular}

\subsection{Livestock Carrying Capacity for Grassland}

Livestock carrying capacity for grassland varied in different time periods. In summer, grassland had the highest livestock carrying capacity, with a livestock number of 237.46 thousand cattle-units. In autumn and winter, the carrying capacity of grassland 
was the lowest, with a total of 79.81 thousand cattle-units. This means that if the livestock number was maintained except for summer, large number of other forage and fodder must be supplemented. The spatial distribution of livestock carrying capacity in different grazing seasons can be seen in Figure 3.
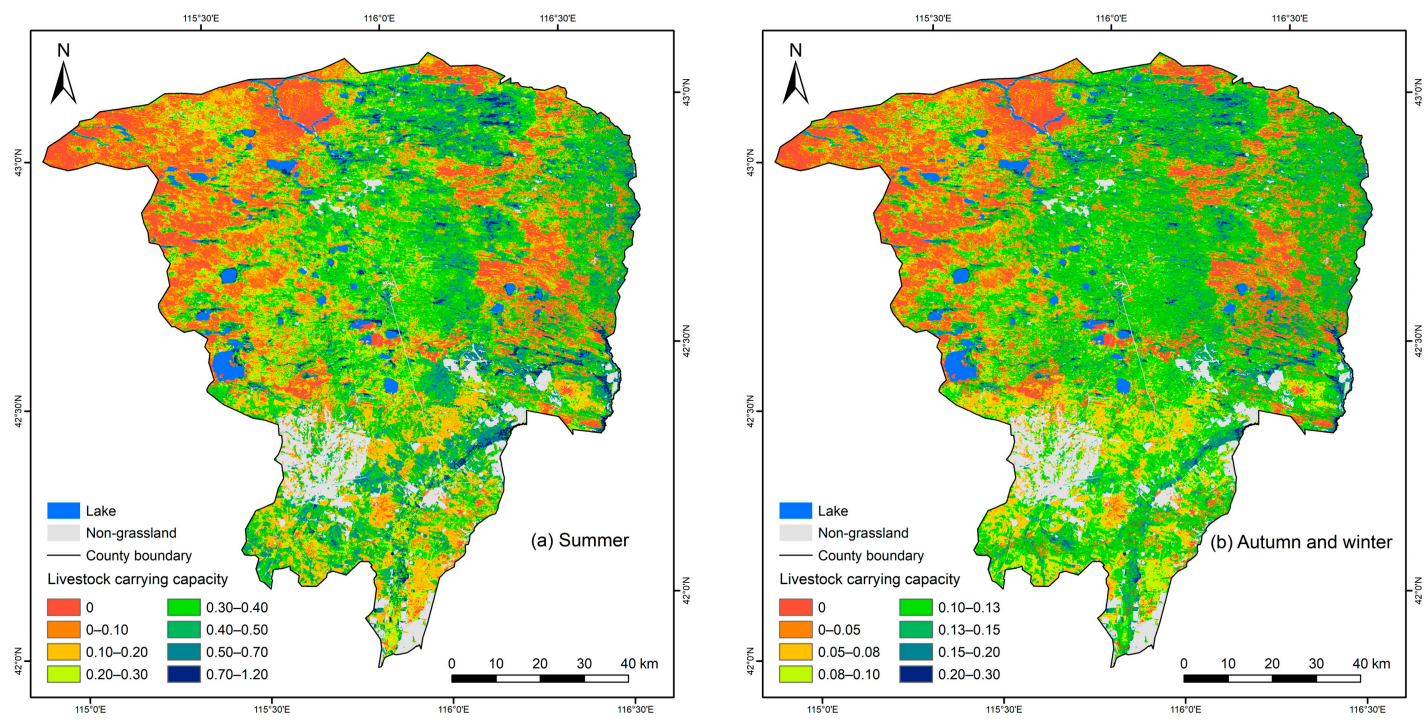

Figure 3. Assessed livestock carrying capacity (unit: cattle-unit/ha) throughout grazing season according to the carrying capacity model that considers available grass yield determined for different grassland resources conditions as in Figure 2.

At the Gacha-scale, in areas where grazing was allowed, the livestock density in summer ranged from 0.06 cattle-unit/ha in Wuritutala to 0.42 cattle-unit/ha in Caiyuan. The Wuyi breeding farm could carry the largest number of livestock at 18,847 cattle-units, more than double the number of livestock carried by Narisitu, which carried the second largest number of livestock. In autumn and winter, the Gacha with the highest and lowest stocking density was consistent with that in summer. The stocking density in autumn and winter ranged from 0.03 cattle-unit/ha to 0.13 cattle-unit/ha. Figure 4 demonstrates the gradual increasing trend of livestock carrying capacity radiating outward from the southeast corner. The northwestern Gachas had the lowest carrying capacity, with a carrying capacity of less than 0.2 cattle-unit/ha in summer, less than 0.06 cattle-unit/ha in autumn and winter.
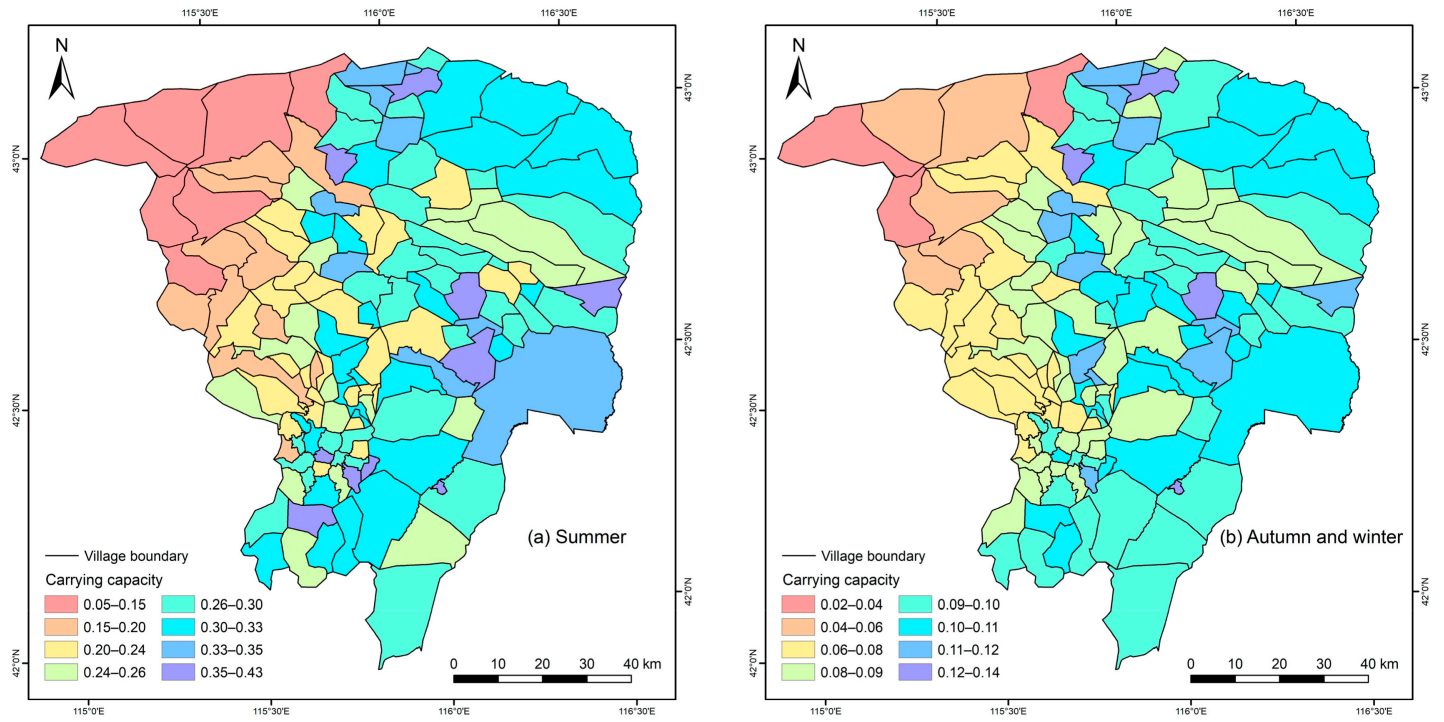

Figure 4. Spatial distribution of livestock carrying capacity (unit: cattle-unit/ha) in different grazing seasons at the Gacha-scale. 


\subsection{Current Status of Livestock Overload}

To provide a more realistic picture of the current livestock carrying status, the livestock carrying capacity in summer was taken for further evaluation. Because livestock feed mainly comes from natural grassland in summer, supplementary feeding is necessary in other grazing seasons. The actual stocking rate of 109 Gachas in Zhenglan Banner totaled 283.32 thousand cattle-units in summer. The overload rate was $19.32 \%$ compared to carrying capacity in summer. At the Gacha-scale, the results of the livestock overloading rate assessment revealed that 71 Gachas exhibited livestock overload. Twenty-four Gachas had an overloading rate greater than $100 \%, 18$ Gachas had a livestock overloading rate between $-10 \%$ and $10 \%$, where basic balance was maintained between grass and livestock. Additionally, 20 Gachas still had some grazing potential. The spatial distribution of actual stocking rate and livestock overloading rates demonstrates that the Gachas with higher stocking rate were mainly concentrated in the southwestern part (Figure 5).
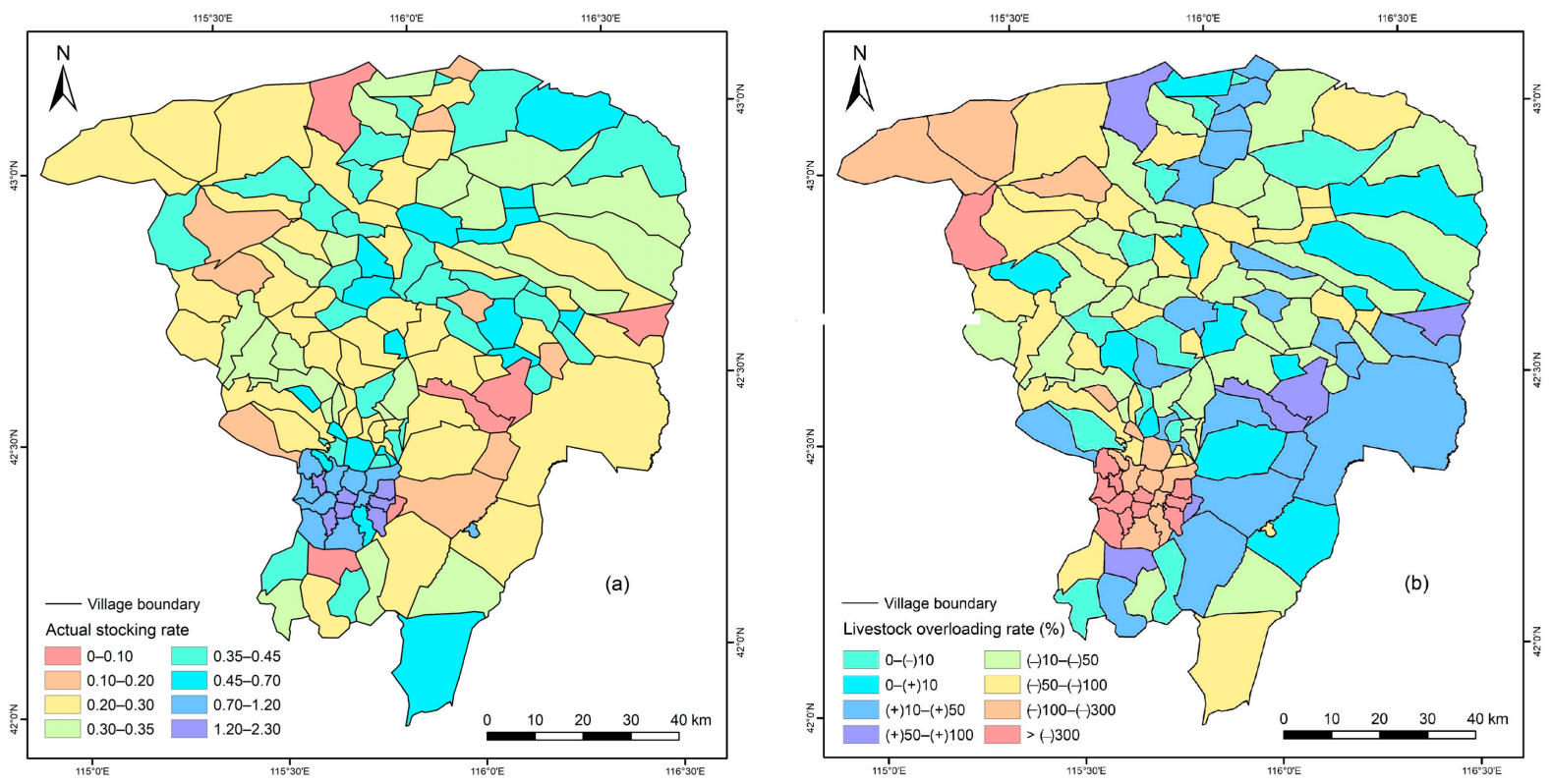

Figure 5. Spatial distribution of (a) actual stocking rate (unit: cattle-unit/ha) and (b) livestock overloading rate in summer at the Gacha-scale.

\section{Discussion}

\subsection{Improvement of the NPP-Based Grass Yield Estimation Model}

Zhenglan Banner is located in an arid and semi-arid region, with large seasonal variations in grass yield, accompanied by significant spatial heterogeneity $[104,105]$. The NPP-based grass yield estimation model in this study constructed by fusing high spatialtemporal resolution remotely sensed data and optimized CASA model could achieve more detailed spatial delineation and capture intra-annual dynamic. In addition, the stability and transferability of the estimation model are better than those of the widely used statistical models. On the other hand, the high spatial resolution of grass yield estimation results also contribute to improve the accuracy of livestock carrying capacity assessment at the Gacha-scale. Based on this, we conclude that the grass yield estimation model has the appeal of being implemented in drylands.

The accuracy of the grass yield estimation model depends mainly on the NPP estimation error. In the CASA model used to estimate NPP in this study, modelling of different maximum light use efficiencies according to different vegetation characteristics can minimize estimation errors. In the original CASA model, the maximum light use efficiency is set to $0.389 \mathrm{gC} \cdot \mathrm{MJ}^{-1}$ for all vegetation types in the world $[106,107]$. However, it was proved that this constant assignment is not appropriate in different vegetation types as 
it may be affected by various influencing factors, such as local temperature, moisture, soil conditions, and plant individual development [108-110]. Many previous studies involving the study area estimated the maximum light use efficiency for grassland with reference to the results of a large-scale field survey, and with values ranging from 0.45 to $0.542 \mathrm{gC} \cdot \mathrm{MJ}^{-1}[74,110,111]$. In this study, the maximum light energy use efficiency of grassland, which was re-optimized for the sparse vegetation cover and relatively complex surface conditions in the study area, was determined from our previous study $[96,97]$ with a value of $0.518 \mathrm{gC} \cdot \mathrm{MJ}^{-1}$, which is similar to the results of published studies by other scholars.

The proportion of NPP allocated to above-ground growth has received far less attention $[112,113]$ and is likely to be an uncertain parameter in the estimation of grass yield. This study directly used the default proportional factor in semi-arid grassland reported by the Intergovernmental Panel on Climate Change (IPCC) [94] as a model parameter for the entire study area. While at the community level, the NPP allocation proportions still differs across grassland types [114-116]. Future research will need to determine the proportion of NPP allocated to the above-ground component of different grassland vegetation types by obtaining measured data of below- and above-ground growth as a way to improve estimation accuracy and provide support for long-term grass yield estimation.

When this model is desired to be implemented in different places, its good performance in application in the grasslands of Zhenglan Banner does not necessarily mean that it will function with the same accuracy in grassland biomes elsewhere. This is because in the process of grass yield estimation in typical steppe, although the vegetation homogenization is relatively high, there are still differences in vegetation types. Since the typical steppe area in this study is small, the vegetation types are less different and all belong to typical steppe types, and the grass yield estimation model also takes into account the influence of non-vegetation factors such as topography and climate, so it does not have much influence on the estimation accuracy. Given this uncertainty, we recommend that when implementing this estimation model in other situations, efforts should be made to validate its grass yield estimation results based on observations in the field.

\subsection{Performance of the Grassland Resource Utilization Patterns}

In Zhenglan Banner, grassland resources are mainly located in sandy land, followed by typical steppe (Figure 1c). According to the distribution characteristics of grassland in Zhenglan Banner, the key factors for sustainable utilization of grassland resources are the degree of sand mobility and the degradation condition of typical steppe. In this study, the grazing strategies and proper use factors were developed based on the two factorsnamely, the degree of sand mobility and the degradation condition of typical steppe, with the aim of coping with the spatial heterogeneity of grassland resources and achieving the sustainable utilization of grassland resources. On this basis, the intensity of grassland utilization was developed by dividing grazing seasons with the purpose of preventing seasonal overload of grassland resources. The maximum value of the proper use factors in the pattern were proved to be reasonable by comparison with the grassland proper use factors used in published livestock carrying capacity studies in the study area and the region covering the study area [84,117-119].

There is still room for further refinement of the pattern, for example, by considering the species composition, nutrient quality, and soil condition of grassland resources [29]. The spatial and temporal variation in species composition of grassland resources is an essential step in evaluating grassland health and developing grassland management strategies and can be achieved by high spatial resolution image classification [120]. The nutritional quality of grassland directly affects the growth of livestock and the quality of livestock products. The use of hyperspectral remote sensing technology may deeply depict the dynamic changes in the nutritional quality of natural grassland [121]. Soil condition is a key driver for grassland growth and quality [122]. The availability of global soil maps that provide such information, such as SoilGrids [123], will likely include the effects of soil 
texture or K-factor or soil erodibility, which have recently been modeled using soil texture data from SoilGrids [124]. These factors will be considered when developing grassland utilization patterns in future work. Meanwhile, how to weigh the synergistic relationship of each impact factor and achieve the integrated use of factors is also a key we are prepared to address subsequently.

When the pattern was applied to the summer grassland of Zhenglan Banner, our carrying capacity assessment resulted in an average stocking density of 0.26 cattle-unit/ha. This figure is slightly below the stocking density for the summer grassland prescribed by the Zhenglan Banner government of 0.3 cattle-unit/ha [125]. The difference is understandable because our assessment focused on achieving ecological restoration. Zhang et al. [126] reviewed the typical grassland stocking density proposed in Inner Mongolia ranging from 0.25 to 0.48 cattle-unit/ha, which is consistent with the stocking density in this paper. The assessment results of this study provide information on geographic and seasonal variations in carrying capacity, which can support stakeholder decisions, such as implementing more sustainable stocking rates, determining reasonable number of livestock for sale, and providing some reference to the amount of fodder purchased. In addition, the application of high spatiotemporal remote sensing technology can ensure that livestock carrying capacity estimations at the spatial scale of the Gacha is more refined, which facilitates the implementation of grassland utilization strategies.

The grassland resource utilization patterns of this study were constructed for the animal husbandry dominated by grazing, which can be better applied to grazing livestock production system with a long production cycle (winter and spring can be supplemented with some concentrates) and seasonal rest grazing production system widely implemented in grassland pastoral areas. Hence, this method does not apply to livestock production systems based on grain concentrates and straw fodder in agricultural areas and to shortterm fattening production systems. On the other hand, these two livestock production systems have a little direct impact on grassland, so there is no need for general grasslivestock balance management [127]. When we conducted a reasonableness analysis of the Gachas with overload rates greater than $150 \%$ in Zhenglan Banner, it was found that (Figure 5b), except for Bayanhanggai Gacha and Bayannaoer Gacha, all of the Gachas were located in agricultural areas where livestock are raised on grain concentrates and straw fodder. These results are not indicative because the estimated carrying capacity was not suitable for use in this area. Exclusion of the Gachas where carrying capacity estimates are not applicable, 51 Gachas exhibited livestock overload.

Zhenglan Banner is a typical pastoral area. More than $70 \%$ of the total population are herdsmen whose income mainly depends on traditional grassland animal husbandry [128]. If the number of livestock is controlled strictly according to the grassland resource utilization pattern of this study, it will certainly affect the income of herders, thus making the implementation of the grassland utilization model more difficult. Therefore, while implementing the regulation of a grassland resource utilization pattern, the local government should promote the transformation of traditional grassland animal husbandry to modern grassland ecological animal husbandry with large-scale breeding and intensive operation. By cultivating small areas of high-yielding and high-efficiency artificial grassland, the high-quality forage needed for livestock development can be met $[5,9,129]$. By exploiting the ecological tourism value and developing special forest, sand, and grass industries, the income of local herdsmen is improved. In this case, the regulation of grassland resource utilization pattern can be implemented in a sustainable manner.

\section{Conclusions}

To achieve sustainable use of grassland resources, we developed the grassland resource utilization patterns for three grazing seasons based on the degree of sand mobility and typical steppe degradation and completed the estimation of grassland carrying capacity. Through the regulation of spatiotemporal utilization pattern, the annual available grass yield in Zhenglan Banner was estimated to be $625.76 \mathrm{kt}$, with $0 \mathrm{kt}$ of available grass 
yield in spring, $416.78 \mathrm{kt}$ in summer, and $208.98 \mathrm{kt}$ in autumn and winter. The grassland carrying capacity in summer was 237.46 thousand cattle-units. The grassland carrying capacity in autumn and winter was 79.81 thousand cattle-units. The grassland resources of Zhenglan Banner are being overgrazed, with an overloading rate of $19.32 \%$. Fifty-one Gachas exhibited livestock overload. It is advisable to reduce the current stocking density.

The spatiotemporal utilization patterns for grassland resources proposed in this paper have the potential to be replicated in other regions. The utilization pattern is not only able to cope with the high spatial and temporal heterogeneity of grasslands in drylands but also contributes to the ecological restoration of grasslands. Grassland degradation is a widespread problem in northern grasslands in China, and we therefore suggest using this pattern to provide technical support for the entire northern dryland region of China. Nevertheless, there is still room for further improvement in the accuracy of grassland carrying capacity estimation. In our future work, we will improve the accuracy of grass yield estimation and perfect spatiotemporal utilization patterns for grassland resources.

Author Contributions: Conceptualization, Z.G., P.Q., and Z.L.; methodology, Z.G. and B.S.; software, Y.L. and P.Q.; validation, T.G., Z.Y., and P.Q.; formal analysis, B.S. and Z.G.; investigation, P.Q., B.S., Z.G., Y.L., Z.Y., and T.G.; resources, Z.G. and B.S.; data curation, Y.L. and Z.Y.; writing-original draft preparation, P.Q.; writing—review and editing, B.S., P.Q., and Z.G.; visualization, P.Q.; supervision, Z.G. and Z.L. All authors have read and agreed to the published version of the manuscript.

Funding: This research was supported by "the Fundamental Research Funds for the Central Nonprofit Research Institution of CAF", grant number CAFYBB2020ZB001, Inner Mongolia Autonomous Region Financial Special Project.

Institutional Review Board Statement: Not applicable.

Informed Consent Statement: Not applicable.

Data Availability Statement: Data can be provided upon request from the corresponding author.

Acknowledgments: We would like to thank the government of Zhenglan Banner for its full support and cooperation in the field investigations and basic data acquisition.

Conflicts of Interest: The authors declare no conflict of interest.

\section{References}

1. The Food and Agriculture Organization of the United Nations. NSP-Grasslands, Rangelands and Forage Crops. Available online: http:/ / www.fao.org/agriculture/crops/thematic-sitemap/theme/spi/grasslands-rangelands-and-forage-crops/en/ (accessed on 6 March 2021).

2. Xu, B.; Yang, X.; Tao, W.; Miao, J.; Yang, Z.; Liu, H.; Jin, Y.; Zhu, X.; Qin, Z.; Lv, H. MODIS-based remote-sensing monitoring of the spatiotemporal patterns of China's grassland vegetation growth. Int. J. Remote Sens. 2013, 34, 3867-3878. [CrossRef]

3. Fassnacht, F.E.; Li, L.; Fritz, A. Mapping degraded grassland on the Eastern Tibetan Plateau with multi-temporal Landsat 8 data-Where do the severely degraded areas occur? Int. J. Appl. Earth Obs. Geoinf. 2015, 42, 115-127. [CrossRef]

4. Zhao, F.; Xu, B.; Yang, X.; Jin, Y.; Li, J.; Xia, L.; Chen, S.; Ma, H. Remote sensing estimates of grassland aboveground biomass based on MODIS net primary productivity (NPP): A case study in the Xilingol grassland of Northern China. Remote Sens. 2014, 6, 5368-5386. [CrossRef]

5. Zhang, X.; Tang, H.; Dong, X.; Li, B.; Huang, Y.; Gong, J. The dilemma of steppe and it's transformation in China. Chin. Sci. Bull. 2016, 61, 165-177.

6. State Forestry and Grassland Administration: Improve Grassland Protection and Restoration System to Build a National Ecological Security Barrier. Available online: http:/ /www.gov.cn/xinwen/2020-01/07/content_5467134.htm (accessed on 22 February 2021).

7. Zhan, S.; Zheng, S.; Wang, Y.; Bai, Y. Response and correlation of above-and below-ground functional traits of Leymus chinensis to nitrogen and phosphorus additions. Chin. J. Plant Ecol. 2016, 40, 36.

8. Hobbs, R.J.; Huenneke, L.F. Disturbance, diversity, and invasion: Implications for conservation. Conserv. Biol. $1992,6,324-337$. [CrossRef]

9. Fang, J.; Jing, H.; Zhang, W.; Gao, S.; Duan, Z.; Wang, H.; Zhong, J.; Pan, Q.; Zhao, K.; Bai, W. The concept of “Grass-based Livestock Husbandry" and its practice in Hulun Buir, Inner Mongolia. Chin. Sci. Bull. 2018, 63, 1619-1631. [CrossRef]

10. Hua, L.; Squires, V.R. Managing China's pastoral lands: Current problems and future prospects. Land Use Policy 2015, $43,129-137$. [CrossRef] 
11. Shen, H.; Zhu, Y.; Zhao, X.; Geng, X.; Gao, S.; Fang, J. Analysis of current grassland resources in China. Chin. Sci. Bull. 2016, 61, 139-154.

12. Briske, D.D.; Zhao, M.; Han, G.; Xiu, C.; Kemp, D.R.; Willms, W.; Havstad, K.; Kang, L.; Wang, Z.; Wu, J. Strategies to alleviate poverty and grassland degradation in Inner Mongolia: Intensification vs production efficiency of livestock systems. J. Environ. Manag. 2015, 152, 177-182. [CrossRef] [PubMed]

13. Tong, C.; Wu, J.; Yong, S.-P.; Yang, J.; Yong, W. A landscape-scale assessment of steppe degradation in the Xilin River Basin, Inner Mongolia, China. J. Arid Environ. 2004, 59, 133-149. [CrossRef]

14. Yu, M.; Ellis, J.E.; Epstein, H.E. Regional analysis of climate, primary production, and livestock density in Inner Mongolia. J. Environ. Qual. 2004, 33, 1675-1681. [CrossRef]

15. Luo, G.; Han, Q.; Zhou, D.; Li, L.; Chen, X.; Li, Y.; Hu, Y.; Li, B.L. Moderate grazing can promote aboveground primary production of grassland under water stress. Ecol. Complex. 2012, 11, 126-136. [CrossRef]

16. Calef, W. Range Management: Principles and Practices; Taylor \& Francis: Abingdon, UK, 1953.

17. Hedrick, D.W. Proper utilization: A problem in evaluating the physiological response of plants to grazing use: A review. Rangel. Ecol. Manag./J. Range Manag. Arch. 1958, 11, 34-43. [CrossRef]

18. Li, M.; Guo, X. Long Term Effect of Major Disturbances on the Northern Mixed Grassland Ecosystem-A Review. Open J. Ecol. 2014, 4, 214-233. [CrossRef]

19. Du, B.; Zhen, L.; Hu, Y.; Yan, H.; De Groot, R.; Leemans, R. Comparison of ecosystem services provided by grasslands with different utilization patterns in China's Inner Mongolia Autonomous Region. J. Geogr. Sci. 2018, 28, 1399-1414. [CrossRef]

20. Wang, D.; Wang, L. A new perspective on the concept of grassland management. Chin. Sci. Bull. 2019, 64, 1106-1113. [CrossRef]

21. Liu, C.; Wang, L.; Song, X.; Chang, Q.; Frank, D.A.; Wang, D.; Li, J.; Lin, H.; Du, F. Towards a mechanistic understanding of the effect that different species of large grazers have on grassland soil N availability. J. Ecol. 2018, 106, 357-366. [CrossRef]

22. Roe, E.M. On rangeland carrying capacity. Rangel. Ecol. Manag./J. Range Manag. Arch. 1997, 50, 467-472.

23. Adams, B.; Ehlert, G.; Stone, C.; Lawrence, D.; Alexander, M.; Willoughby, M.; Hincz, C.; Moisey, D.; Burkinshaw, A.; Carlson, J. Rangeland Health Assessment for Grassland, Forest and Tame Pasture; Alberta Sustainable Resource Development, Lands Division, Rangeland Management Branch: Lethbridge, AB, Canada, 2009.

24. Launchbaugh, K. Forage Production and Carrying Capacity: Guidelines for Setting a Proper Stocking Rate; University of Idaho: Moscow, ID, USA, 2014.

25. Yang, Y.; Wang, J.; Chen, Y.; Cheng, F.; Liu, G.; He, Z. Remote-Sensing Monitoring of Grassland Degradation Based on the GDI in Shangri-La, China. Remote Sens. 2019, 11, 3030. [CrossRef]

26. Doan, T.; Guo, X. Understanding bison carrying capacity estimation in Northern Great Plains using remote sensing and GIS. Can. J. Remote Sens. 2019, 45, 139-162. [CrossRef]

27. Reeves, M.C.; Robert, A.; Angerer, J.; Hunt, E.R., Jr.; Wasantha, R.; Kumar, L. Global view of remote sensing of rangelands: Evolution, applications, future pathways. In Land Resources Monitoring, Modeling, and Mapping with Remote Sensing; CRC Press Inc.: Boca Raton, FL, USA, 2015; pp. 237-266.

28. Steenweg, R.; Hebblewhite, M.; Gummer, D.; Low, B.; Hunt, B. Assessing potential habitat and carrying capacity for reintroduction of plains bison (Bison bison bison) in Banff National Park. PLoS ONE 2016, 11, e0150065. [CrossRef]

29. Ali, I.; Cawkwell, F.; Dwyer, E.; Barrett, B.; Green, S. Satellite remote sensing of grasslands: From observation to management. J. Plant Ecol. 2016, 9, 649-671. [CrossRef]

30. Kuang, W.; Yan, H.; Zhang, S.; Li, X.; Bao, Z.; Ning, J.; Zhang, P.A.; Fan, B.; Wang, S. Forage-livestock status in farms and ranches of ecological grass-animal husbandry construction and allocation model of grain-warp-feed in Hulunbuir Agricultural Reclamation Group. Chin. Sci. Bull. 2018, 63, 1711-1721. [CrossRef]

31. Hunt, E.R., Jr.; Everitt, J.H.; Ritchie, J.C.; Moran, M.S.; Booth, D.T.; Anderson, G.L.; Clark, P.E.; Seyfried, M.S. Applications and research using remote sensing for rangeland management. Photogramm. Eng. Remote Sens. 2003, 69, 675-693. [CrossRef]

32. Hunt, E.R., Jr.; Miyake, B.A. Comparison of stocking rates from remote sensing and geospatial data. Rangel. Ecol. Manag. 2006, 59, 11-18. [CrossRef]

33. Hunt, L.P. Safe pasture utilisation rates as a grazing management tool in extensively grazed tropical savannas of northern Australia. Rangel. J. 2008, 30, 305-315. [CrossRef]

34. Reinermann, S.; Asam, S.; Kuenzer, C. Remote Sensing of Grassland Production and Management-A Review. Remote Sens. 2020, 12, 1949. [CrossRef]

35. Ma, W. Study on Methods for Grassland Classification and Quality Estimation by Remote Sensing: A Case Study in the Region around Qinghai Lake; Shanghai Institute of Technical Physics of the Chinese Academy of Sciences: Shanghai, China, 2015.

36. Gholami Baghi, N.; Oldeland, J. Do soil-adjusted or standard vegetation indices better predict above ground biomass of semi-arid, saline rangelands in North-East Iran? Int. J. Remote Sens. 2019, 40, 8223-8235. [CrossRef]

37. Ren, H.; Zhou, G. Estimating green biomass ratio with remote sensing in arid grasslands. Ecol. Indic. 2019, 98, 568-574. [CrossRef]

38. Shoko, C.; Mutanga, O.; Dube, T. Progress in the remote sensing of C3 and C4 grass species aboveground biomass over time and space. ISPRS J. Photogramm. Remote Sens. 2016, 120, 13-24. [CrossRef]

39. Yang, S.; Feng, Q.; Liang, T.; Liu, B.; Zhang, W.; Xie, H. Modeling grassland above-ground biomass based on artificial neural network and remote sensing in the Three-River Headwaters Region. Remote Sens. Environ. 2018, 204, 448-455. [CrossRef] 
40. Tucker, C.; Vanpraet, C.; Boerwinkel, E.; Gaston, E.A. Satellite remote sensing of total dry matter production in the Senegalese Sahel. Remote Sens. Environ. 1983, 13, 461-474. [CrossRef]

41. Tucker, C.J.; Vanpraet, C.L.; Sharman, M.; Van Ittersum, G. Satellite remote sensing of total herbaceous biomass production in the Senegalese Sahel: 1980-1984. Remote Sens. Environ. 1985, 17, 233-249. [CrossRef]

42. Liu, S.; Cheng, F.; Dong, S.; Zhao, H.; Hou, X.; Wu, X. Spatiotemporal dynamics of grassland aboveground biomass on the Qinghai-Tibet Plateau based on validated MODIS NDVI. Sci. Rep. 2017, 7, 1-10. [CrossRef]

43. Jin, Y.; Yang, X.; Qiu, J.; Li, J.; Gao, T.; Wu, Q.; Zhao, F.; Ma, H.; Yu, H.; Xu, B. Remote sensing-based biomass estimation and its spatio-temporal variations in temperate grassland, Northern China. Remote Sens. 2014, 6, 1496-1513. [CrossRef]

44. Eisfelder, C.; Kuenzer, C.; Dech, S. Derivation of biomass information for semi-arid areas using remote-sensing data. Int. J. Remote Sens. 2012, 33, 2937-2984. [CrossRef]

45. Eisfelder, C.; Klein, I.; Bekkuliyeva, A.; Kuenzer, C.; Buchroithner, M.F.; Dech, S. Above-ground biomass estimation based on NPP time-series- A novel approach for biomass estimation in semi-arid Kazakhstan. Ecol. Indic. 2017, 72, 13-22. [CrossRef]

46. Quan, X.; He, B.; Yebra, M.; Yin, C.; Liao, Z.; Zhang, X.; Li, X. A radiative transfer model-based method for the estimation of grassland aboveground biomass. Int. J. Appl. Earth Obs. Geoinf. 2017, 54, 159-168. [CrossRef]

47. Punalekar, S.M.; Verhoef, A.; Quaife, T.L.; Humphries, D.; Bermingham, L.; Reynolds, C.K. Application of Sentinel-2A data for pasture biomass monitoring using a physically based radiative transfer model. Remote Sens. Environ. 2018, 218, 207-220. [CrossRef]

48. Lunagaria, M.M.; Patel, H.R. Evaluation of PROSAIL inversion for retrieval of chlorophyll, leaf dry matter, leaf angle, and leaf area index of wheat using spectrodirectional measurements. Int. J. Remote Sens. 2019, 40, 8125-8145. [CrossRef]

49. He, L.; Li, A.; Yin, G.; Nan, X.; Bian, J. Retrieval of grassland aboveground biomass through inversion of the PROSAIL model with MODIS imagery. Remote Sens. 2019, 11, 1597. [CrossRef]

50. Berger, K.; Atzberger, C.; Danner, M.; D’Urso, G.; Mauser, W.; Vuolo, F.; Hank, T. Evaluation of the PROSAIL model capabilities for future hyperspectral model environments: A review study. Remote Sens. 2018, 10, 85. [CrossRef]

51. Donald, G.; Gherardi, S.; Edirisinghe, A.; Gittins, S.; Henry, D.; Mata, G. Using MODIS imagery, climate and soil data to estimate pasture growth rates on farms in the south-west of Western Australia. Anim. Prod. Sci. 2010, 50, 611-615. [CrossRef]

52. Hill, M.J.; Donald, G.E.; Hyder, M.W.; Smith, R.C. Estimation of pasture growth rate in the south west of Western Australia from AVHRR NDVI and climate data. Remote Sens. Environ. 2004, 93, 528-545. [CrossRef]

53. Sun, B.; Li, Z.; Gao, Z.; Guo, Z.; Wang, B.; Hu, X.; Bai, L. Grassland degradation and restoration monitoring and driving forces analysis based on long time-series remote sensing data in Xilin Gol League. Acta Ecol. Sin. 2017, 37, 219-228. [CrossRef]

54. Zhang, Y.; Qi, W.; Zhou, C.; Ding, M.; Liu, L.; Gao, J.; Bai, W.; Wang, Z.; Zheng, D. Spatial and temporal variability in the net primary production of alpine grassland on the Tibetan Plateau since 1982. J. Geogr. Sci. 2014, 24, 269-287. [CrossRef]

55. Smith, B.; Knorr, W.; Widlowski, J.-L.; Pinty, B.; Gobron, N. Combining remote sensing data with process modelling to monitor boreal conifer forest carbon balances. For. Ecol. Manag. 2008, 255, 3985-3994. [CrossRef]

56. Prince, S.D.; Goward, S.N. Global primary production: A remote sensing approach. J. Biogeogr. 1995, 815-835. [CrossRef]

57. Fan, J.-W.; Shao, Q.-Q.; Liu, J.-Y.; Wang, J.-B.; Harris, W.; Chen, Z.-Q.; Zhong, H.-P.; Xu, X.-L.; Liu, R.-G. Assessment of effects of climate change and grazing activity on grassland yield in the Three Rivers Headwaters Region of Qinghai-Tibet Plateau, China. Environ. Monit. Assess. 2010, 170, 571-584. [CrossRef] [PubMed]

58. You, Y.; Wang, S.; Ma, Y.; Wang, X.; Liu, W. Improved modeling of gross primary productivity of Alpine Grasslands on the Tibetan Plateau using the biome-BGC model. Remote Sens. 2019, 11, 1287. [CrossRef]

59. Knorr, W.; Heimann, M. Impact of drought stress and other factors on seasonal land biosphere CO2 exchange studied through an atmospheric tracer transport model. Tellus B 1995, 47, 471-489. [CrossRef]

60. Ruimy, A.; Dedieu, G.; Saugier, B. TURC: A diagnostic model of continental gross primary productivity and net primary productivity. Glob. Biogeochem. Cycles 1996, 10, 269-285. [CrossRef]

61. Veroustraete, F.; Sabbe, H.; Eerens, H. Estimation of carbon mass fluxes over Europe using the C-Fix model and Euroflux data. Remote Sens. Environ. 2002, 83, 376-399. [CrossRef]

62. Maselli, F.; Argenti, G.; Chiesi, M.; Angeli, L.; Papale, D. Simulation of grassland productivity by the combination of ground and satellite data. Agric. Ecosyst. Environ. 2013, 165, 163-172. [CrossRef]

63. Xiao, X.; Hollinger, D.; Aber, J.; Goltz, M.; Davidson, E.A.; Zhang, Q.; Moore, B., III. Satellite-based modeling of gross primary production in an evergreen needleleaf forest. Remote Sens. Environ. 2004, 89, 519-534. [CrossRef]

64. Yu, R.; Evans, A.; Malleson, N. Quantifying grazing patterns using a new growth function based on MODIS Leaf Area Index. Remote Sens. Environ. 2018, 209, 181-194. [CrossRef]

65. Brogaard, S.; Runnström, M.; Seaquist, J.W. Primary production of Inner Mongolia, China, between 1982 and 1999 estimated by a satellite data-driven light use efficiency model. Glob. Planet. Chang. 2005, 45, 313-332. [CrossRef]

66. Yuan, W.; Liu, S.; Zhou, G.; Zhou, G.; Tieszen, L.L.; Baldocchi, D.; Bernhofer, C.; Gholz, H.; Goldstein, A.H.; Goulden, M.L. Deriving a light use efficiency model from eddy covariance flux data for predicting daily gross primary production across biomes. Agric. For. Meteorol. 2007, 143, 189-207. [CrossRef]

67. Jia, W.; Liu, M.; Wang, D.; He, H.; Shi, P.; Li, Y.; Wang, Y. Uncertainty in simulating regional gross primary productivity from satellite-based models over northern China grassland. Ecol. Indic. 2018, 88, 134-143. [CrossRef] 
68. Tan, K.; Ciais, P.; Piao, S.; Wu, X.; Tang, Y.; Vuichard, N.; Liang, S.; Fang, J. Application of the ORCHIDEE global vegetation model to evaluate biomass and soil carbon stocks of Qinghai-Tibetan grasslands. Glob. Biogeochem. Cycles 2010, 24. [CrossRef]

69. Parton, W.; Scurlock, J.; Ojima, D.; Gilmanov, T.; Scholes, R.; Schimel, D.S.; Kirchner, T.; Menaut, J.C.; Seastedt, T.; Garcia Moya, E. Observations and modeling of biomass and soil organic matter dynamics for the grassland biome worldwide. Glob. Biogeochem. Cycles 1993, 7, 785-809. [CrossRef]

70. Wang, J.; Li, A.; Bian, J. Simulation of the grazing effects on grassland aboveground net primary production using DNDC model combined with time-series remote sensing data-A case study in Zoige Plateau, China. Remote Sens. 2016, 8, 168. [CrossRef]

71. Reeves, M.C.; Winslow, J.C.; Running, S.W. Mapping weekly rangeland vegetation productivity using MODIS algorithms. J. Range Manag. 2001, 54, A90.

72. Running, S.W.; Thornton, P.E.; Nemani, R.; Glassy, J.M. Global terrestrial gross and net primary productivity from the earth observing system. In Methods in Ecosystem Science; Springer: New York, NY, USA, 2000; pp. 44-57.

73. Chi, D.; Wang, H.; Li, X.; Liu, H.; Li, X. Assessing the effects of grazing on variations of vegetation NPP in the Xilingol Grassland, China, using a grazing pressure index. Ecol. Indic. 2018, 88, 372-383. [CrossRef]

74. Zhao, F.; Xu, B.; Yang, X.; Xia, L.; Jin, Y.; Li, J.; Zhang, W.; Guo, J.; Shen, G. Modelling and analysis of net primary productivity and its response mechanism to climate factors in temperate grassland, northern China. Int. J. Remote Sens. 2019, 40, $2259-2277$. [CrossRef]

75. Zhang, F.; Zhou, G.; Wang, Y. Dynamics simulation of net primary productivity by a satellite data-driven CASA model in Inner Mongolian typical steppe, China. Chin. J. Plant Ecol. 2008, 32, 786.

76. Holechek, J.L.; Gomes, H.D.S.; Molinar, F.; Galt, D. Grazing intensity: Critique and approach. Rangel. Arch. 1998, 20 , 15-18.

77. Zhang, J.; Zhang, L.; Liu, X.; Qiao, Q. Research on Sustainable Development in an Alpine Pastoral Area Based on Equilibrium Analysis Between the Grassland Yield, Livestock Carrying Capacity, and Animal Husbandry Population. Sustainability 2019, 11, 4659. [CrossRef]

78. Neudert, R.; Etzold, J.; Münzner, F.; Manthey, M.; Busse, S. The opportunity costs of conserving pasture resources for mobile pastoralists in the Greater Caucasus. Landsc. Res. 2013, 38, 499-522. [CrossRef]

79. Yu, L.; Zhou, L.; Liu, W.; Zhou, H. Using remote sensing and GIS technologies to estimate grass yield and livestock carrying capacity of alpine grasslands in Golog Prefecture, China. Pedosphere 2010, 20, 342-351. [CrossRef]

80. De Leeuw, J.; Rizayeva, A.; Namazov, E.; Bayramov, E.; Marshall, M.T.; Etzold, J.; Neudert, R. Application of the MODIS MOD 17 Net Primary Production product in grassland carrying capacity assessment. Int. J. Appl. Earth Obs. Geoinf. 2019, 78, 66-76. [CrossRef]

81. Sun, B.; Li, Z.; Gao, W.; Zhang, Y.; Gao, Z.; Song, Z.; Qin, P.; Tian, X. Identification and assessment of the factors driving vegetation degradation/regeneration in drylands using synthetic high spatiotemporal remote sensing Data-A case study in Zhenglanqi, Inner Mongolia, China. Ecol. Indic. 2019, 107, 105614. [CrossRef]

82. Wu, J.; Gao, Z.; Liu, Q.; Li, Z.; Zhong, B. Methods for sandy land detection based on multispectral remote sensing data. Geoderma 2018, 316, 89-99. [CrossRef]

83. Sun, B.; Wang, Y.; Li, Z.; Gao, W.; Wu, J.; Li, C.; Song, Z.; Gao, Z. Estimating Soil Organic Carbon Density in the Otindag Sandy Land, Inner Mongolia, China, for modelling spatiotemporal variations and evaluating the influences of human activities. Catena 2019, 179, 85-97. [CrossRef]

84. Ding, G.; Li, S.; Cai, J.; Zhao, T.; Wang, X.; Ling, X. Pasture resources evaluation and stocking density in Hunshandake Sandy Land: Case study of Zhenglan Banner, Inner Mongolia. Chin. J. Ecol. 2005, 24, 1038-1042.

85. Chi, D.; Wang, H.; Li, X.; Xu, K.; Yu, F. The variability of growing season of different vegetation types in Xilingol League. Pratacultural Sci. 2016, 33, 1825-1834.

86. Li, Y.; Fan, J.; Yu, H. Grazing Exclusion, a choice between biomass growth and species diversity maintenance in Beijing-Tianjin Sand Source Control Project. Sustainability 2019, 11, 1941. [CrossRef]

87. Su, R.; Yu, T.; Dayananda, B.; Bu, R.; Su, J.; Fan, Q. Impact of climate change on primary production of Inner Mongolian grasslands. Glob. Ecol. Conserv. 2020, 22, e00928. [CrossRef]

88. Zhang, J.; Brown, C.; Qiao, G.; Zhang, B. Effect of eco-compensation schemes on household income structures and herder satisfaction: Lessons from the grassland Ecosystem Subsidy and Award Scheme in Inner Mongolia. Ecol. Econ. 2019, 159, 46-53. [CrossRef]

89. Grassland Protection Construction Project Briefing. Available online: https://www.forestry.gov.cn/cys/29/20190327/17173932 7447523.html (accessed on 22 February 2021).

90. The Development of Livestock Industry in Zhenglan Banner from 1949 to 2016. Available online: http:/ /www.zlq.gov.cn/xxgk/ ghtj/201706/t20170604_1768089.html (accessed on 22 February 2021).

91. Chen, J.; Jönsson, P.; Tamura, M.; Gu, Z.; Matsushita, B.; Eklundh, L. A simple method for reconstructing a high-quality NDVI time-series data set based on the Savitzky-Golay filter. Remote Sens. Environ. 2004, 91, 332-344. [CrossRef]

92. Yang, K.; He, J. China Meteorological Forcing Dataset (1979-2018); A Big Earth Data Platform for Three Poles; National Tibetan Plateau Data Center: Beijing, China, 2018.

93. Ministry of Land and Resources of the People's Republic of China. The Second National Land Survey Technical Regulation (TD/T 1014-2007); Ministry of Land and Resources of the People's Republic of China: Beijing, China, 2007. 
94. Eggleston, H.; Buendia, L.; Miwa, K.; Ngara, T.; Tanabe, K. 2006 IPCC Guidelines for National Greenhouse Gas Inventories; Institute for Global Environmental Strategies (IGES): Kanagawa, Japan, 2006.

95. Gao, F.; Masek, J.; Schwaller, M.; Hall, F. On the blending of the Landsat and MODIS surface reflectance: Predicting daily Landsat surface reflectance. IEEE Trans. Geosci. Remote Sens. 2006, 44, 2207-2218.

96. Ding, X. NPP Estimation Using GF-1 Data in Semi Steppe Area-Zhenglan Banner in Inner Mongolia as a Case Study; Chinese Academy of Forestry: Beijing, China, 2016.

97. Sun, B.; Li, Z.; Gao, Z.; Gao, W.; Zhang, Y.; Ding, X.; Li, C. NPP Estimation Using Time-Series GF-1 Data in Sparse Vegetation Area. In Proceedings of the IGARSS 2018-2018 IEEE International Geoscience and Remote Sensing Symposium, Valencia, Spain, 22-27 July 2018; pp. 3971-3974.

98. The General Administration of Quality Supervision, Inspection and Quarantine of the People's Republic of China. Technical Code of Practice on the Sandified Land Monitoring (GB/T 24255-2009); State Forestry Administration: Beijing, China, 2009.

99. The General Administration of Quality Supervision, Inspection and Quarantine of the People's Republic of China. Parameters for Degradation, Sandification and Salification of Rangelands (GB19377-2003); Ministry of Agriculture of China: Beijing, China, 2004.

100. Ministry of Agriculture and Rural Affairs of the People's Republic of China. Calculation of Rangeland Carrying Capacity (NY/T 635-2015); Ministry of Agriculture of China: Beijing, China, 2015.

101. Cui, Q.; Liu, G.; Zhuo, Y. The preliminary study on dynamic of the grass preservation rates in Xilinguole grassland in the cold season. Chin. J. Grassl. 2009, 31, 102-108.

102. The Cattle Turns the Zhenglan Banner on the Way to a Well off Life. Available online: http://nm.people.com.cn/n2/2020/0711 / c196667-34149026.html (accessed on 22 February 2021).

103. Zhenglan Banner Embarked on a High Quality Development Road with Cattle as the Leading Industry. Available online: http://www.xlgl.gov.cn/zt/zdgz/jyzn/202011/t20201110_2559284.html (accessed on 22 February 2021).

104. Peters, D.; Havstad, K. Nonlinear dynamics in arid and semi-arid systems: Interactions among drivers and processes across scales. J. Arid Environ. 2006, 65, 196-206. [CrossRef]

105. Zha, T.; Kellomäki, S.; Wang, K.Y.; Rouvinen, I. Carbon sequestration and ecosystem respiration for 4 years in a Scots pine forest. Glob. Chang. Biol. 2004, 10, 1492-1503. [CrossRef]

106. Potter, C.S.; Randerson, J.T.; Field, C.B.; Matson, P.A.; Vitousek, P.M.; Mooney, H.A.; Klooster, S.A. Terrestrial ecosystem production: A process model based on global satellite and surface data. Glob. Biogeochem. Cycles 1993, 7, 811-841. [CrossRef]

107. Field, C.B.; Randerson, J.T.; Malmström, C.M. Global net primary production: Combining ecology and remote sensing. Remote Sens. Environ. 1995, 51, 74-88. [CrossRef]

108. Ye, X.; Meng, Y.; Xu, L.; Xu, C. Net primary productivity dynamics and associated hydrological driving factors in the floodplain wetland of China's largest freshwater lake. Sci. Total Environ. 2019, 659, 302-313. [CrossRef]

109. Zhang, M.; Lal, R.; Zhao, Y.; Jiang, W.; Chen, Q. Estimating net primary production of natural grassland and its spatio-temporal distribution in China. Sci. Total Environ. 2016, 553, 184-195. [CrossRef]

110. Zhu, W.; Pan, Y.; Zhang, J. Estimation of net primary productivity of Chinese terrestrial vegetation based on remote sensing. Chin. J. Plant Ecol. 2007, 31, 413.

111. Yang, Y.; Li, L.; Wang, B.; Song, X.; Liu, A.; Wang, M. Simulation of net primary productivity by a satellite data-driven improved CASA model in Xilingol grassland. Chin. J. Ecol. 2015, 34, 2344.

112. Hui, D.; Jackson, R.B. Geographical and interannual variability in biomass partitioning in grassland ecosystems: A synthesis of field data. New Phytol. 2006, 169, 85-93. [CrossRef]

113. Ma, W.; Yang, Y.; He, J.; Zeng, H.; Fang, J. Above-and belowground biomass in relation to environmental factors in temperate grasslands, Inner Mongolia. Sci. China Ser. C Life Sci. 2008, 51, 263-270. [CrossRef]

114. Jackson, R.; Canadell, J.; Ehleringer, J.R.; Mooney, H.; Sala, O.; Schulze, E.D. A global analysis of root distributions for terrestrial biomes. Oecologia 1996, 108, 389-411. [CrossRef] [PubMed]

115. Cairns, M.A.; Brown, S.; Helmer, E.H.; Baumgardner, G.A. Root biomass allocation in the world's upland forests. Oecologia 1997, 111, 1-11. [CrossRef]

116. Hu, F.; Yan, Y.; Liu, L.; Cao, Y.; Ma, Y.; Chen, M.; Liu, Z. Biomass allocation patterns in the temperate typical steppe of Inner Mongolia. Acta Prataculturae Sin. 2017, 26, 33-42.

117. Cao, Z. Temporal and Spatial Charavteristics of Grass Yield and Analysis of Grass-Livestock Balance in Xilingol League from 2000 to 2017; Inner Mongolia University: Hohhot, China, 2019.

118. Zhang, C.; Zhao, X.; Yang, L.; Chao, L.; Han, F.; Jiang, X.; Wang, M. Spatial and temporal dynamic simulation of grazing capacity in Inner Mongolia Grassland based on CENTURY model. J. Arid Land Resour. Environ. 2016, 11, 197-202.

119. Zhang, C.; Wang, M.; Zhao, X.; Guo, R.; Sun, X. Analysis of balance between livestock and feeds in xilingol grassland. Chin. J. Grassl. 2011, 3, 87-93.

120. Lu, B.; He, Y. Species classification using Unmanned Aerial Vehicle (UAV)-acquired high spatial resolution imagery in a heterogeneous grassland. ISPRS J. Photogramm. Remote Sens. 2017, 128, 73-85. [CrossRef]

121. Singh, L.; Mutanga, O.; Mafongoya, P.; Peerbhay, K. Remote sensing of key grassland nutrients using hyperspectral techniques in KwaZulu-Natal, South Africa. J. Appl. Remote Sens. 2017, 11, 036005. [CrossRef]

122. Pullanagari, R.R.; Kereszturi, G.; Yule, I. Integrating airborne hyperspectral, topographic, and soil data for estimating pasture quality using recursive feature elimination with random forest regression. Remote Sens. 2018, 10, 1117. [CrossRef] 
123. Hengl, T.; Mendes de Jesus, J.; Heuvelink, G.B.; Ruiperez Gonzalez, M.; Kilibarda, M.; Blagotić, A.; Shangguan, W.; Wright, M.N.; Geng, X.; Bauer-Marschallinger, B. SoilGrids250m: Global gridded soil information based on machine learning. PLoS ONE 2017, 12, e0169748. [CrossRef] [PubMed]

124. Borrelli, P.; Robinson, D.A.; Fleischer, L.R.; Lugato, E.; Ballabio, C.; Alewell, C.; Meusburger, K.; Modugno, S.; Schütt, B.; Ferro, V. An assessment of the global impact of 21st century land use change on soil erosion. Nat. Commun. 2017, 8, 1-13. [CrossRef]

125. Zhenglan Banner 2020 Government Work Report. Available online: http://www.xlgl.gov.cn/xmxxgk/xsbgt/xxgkml/202005/t2 0200513_2431481.html (accessed on 22 February 2021).

126. Zhang, Y.; Zhang, X.; Wang, X.; Liu, N.; Kan, H. Establishing the carrying capacity of the grasslands of China: A review. Rangel. J. 2014, 36, 1-9. [CrossRef]

127. Li, Q.; Wu, Y. Animal demanding-feed availability balance control series (6)_Animal number monthly change. Pratacultural Sci. 2012, 29, 997-1001.

128. Jiang, G.; Wu, G.; Cheng, D.; Zheng, Y.; Liu, M.; Li, C. Characteristics and designing of eco-husbandry system: A case study in Zhenglan Banner, China. Chin. Sci. Bull. 2016, 61, 224-230.

129. Fang, J.; Pan, Q.; Gao, S.; Jing, H.; Zhang, W. "Small vs large area" principle: Protecting and restoring a large area of natural grassland by establishing a small area of cultivated pasture. Pratacultural Sci. 2016, 33, 1913-1916. 